\title{
BALBÚRDIA, O TROPEL DOS SERES INFORMES
}

\author{
Vinícios Souza de Menezes ${ }^{1}$ \\ IBICT/UFRJ \\ $\underline{\text { menezes.vinicios@gmail.com }}$
}

\begin{abstract}
Resumo
Tem como contexto o Brasil atual, em seus circuitos helênicos e disposições modernas. O Brasil dos fluxos da máquina antropológica ocidental. Entretanto, é também uma escritura a contrapelo, de um Brasil contemporâneo inatual, rodeado por existências virtuais que habitam a orla marginal das falas essenciais. Fora do sentido e da univocidade de um conservadorismo colonial travestido nas roupas do Estado, o inatual é não-oficial (aquele que diz "preferiria não" à ordem), um acidente que irrompe em veredas multivocais nos sulcos escriturais do ofício e, em contingentes toares, aquebrantam as barreiras da língua universal. Este inatual é o ruidoso Brasil dos seres informes e das palavras selvagens, o tropel dos doces bárbaros que avançam através dos grossos portões simbólicomateriais da antiga pólis e seus modernos aparelhos de Estado em busca dos festins da linguagem, dos seus jogos germinantes de alteridade, das suas balbúrdias gramaticais que fertilizam vidas impertinentes ao sentido único. Por esta maneira, este texto é con-temporâneo, ao mesmo tempo, inatual, antigo, moderno e atual. Simultaneamente, carnaval.
\end{abstract}

Palavras-chave: Informe. Seres informes. Marginalização. Universidade.

\section{BALBUDIA, THE TROPEL OF INFORM BEINGS}

\begin{abstract}
It has as context the current Brazil, in its Hellenic circuits and modern dispositions. Brazil from the flows of the western anthropological machine. However, it is also a counter-script, of an unpublished contemporary Brazil, surrounded by virtual existences that inhabit the marginal edge of the essential lines. Out of the meaning and univocity of a colonial conservatism dressed up in state clothing, the unnatural is unofficial (the one that says "would rather not" than order), an accident that erupts in multivocal paths in the scriptural grooves of the office and, in contingents toars, they break down the barriers of the universal language. This unusual is the noisy Brazil of shapeless beings and wild words, the throng of sweet barbarians advancing through the thick material-symbolic gates of the ancient polis and their modern state apparatus in search of the feasts of language, their burgeoning games of otherness. , from their grammatical shambles that fertilize impertinent lives in the one way. In this way, this text is contemporary, at the same time, ineffective, ancient, modern, and present. Simultaneously, carnival.
\end{abstract}

Keywords: Report it Be informed. Marginalization. University.

1 Doutor em Ciência da Informação IBICT/UFRJ

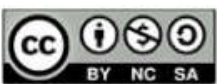

Esta obra está licenciada sob uma Licença Creative Commons Atribuição 4.0 Internacional (CC BY-NC-AS 4.0). LOGEION: Filosofia da informação, Rio de Janeiro, v. 6 n. 1, p.209-233, set.2019/fev. 2020 


\section{O FESTIM DOS DOCES BÁRBAROS}

Com amor no coração

Preparamos a invasão

Cheios de felicidade

Entramos na cidade amada

[...] Avançando através dos grossos portões Nossos planos são muito bons.

[...] Tudo ainda é tal e qual E no entanto nada igual Nós cantamos de verdade E é sempre outra cidade velha Os Mais Doces Bárbaros - Caetano Veloso (1976)

Este texto é uma escritura brasileira con-temporânea. Trata do Brasil contemporâneo, suas dinâmicas de segmentação discursiva e dos avanços da fala unidimensional sob as veste do discurso oficial, desprovido de consistência argumentativa perante a negação da alteridade que constitui não só o pilar comunicativo da esfera pública democrática, mas, a condição de humanidade do mundo. A estratégia de instrumentalização do debate público brasileiro apresenta-se através de elementos clássicos de depreciação e expurgo das personagens dissonantes, desde indivíduos até coletivos. Desde a Antiguidade Clássica Ocidental até a Modernidade certos critérios normativos da linguagem serviram por meio dos seus usos para alijar do logeion (lugar dos discursos) os seres informes (aneu logon / alogon pragma), aqueles desprovidos da harmonia fônica que em uníssono ecoa a Voz (phoné) da Forma (eidos). Os atuais governantes do Estado Brasileiro, filhos do Ocidente e seus dispositivos colonizadores, tentam emular o poder distinto da voz in-formada da autoridade que estigmatizou as operações de governo e ordenamento do mundo Ocidental. Este texto tem por objetivo mostrar como a insígnia da "balbúrdia" proferida pelo atual Ministro da Educação para designar a "escória da educação", a universidade pública, é um dos símbolos ocidentais de representação do "Outro" enquanto o inimigo bárbaro, ao qual os sujeitos "antropocêntricos" deveriam se dirigir com a violência da exceção, sacando suas falas, violando seus corpos.

Períodos históricos distintos, contextos dessemelhantes, formas de vida díspares, reiteram certas práticas políticas, alçando-as ao cânone da opressão. Cessar a fala alheia ou reduzi-la em vitalidade e humanidade é certamente um dos mais típicos artifícios da gramática da identidade. Contudo, como diz a letra da música que epigrafa este tópico introdutório, "Tudo ainda é tal e qual / E no entanto nada igual”. Ou seja, apesar da força ontológica dominante 
seguidamente tentar impor seu princípio fundamental de identidade - grafado logicamente na fórmula $\mathrm{A}=\mathrm{A}$-, para os olhos turvos violados pelo léxico paradoxal do horror e da alegria, da diáspora e das matas, do racismo e do drible, dos algozes e dos xamãs, nenhum A é igual - cada marca, cada grafo habita um ponto de vista no corpo da linguagem (différance).

Este texto aborda temas que envolvem associações adversativas sobre a alteridade. Hospedar no corpo da linguagem uma humanidade disseminada - "os mais doces bárbaros" é, em princípio, cessar com o princípio separatista da ontologia ocidental e seus espectros dicotômicos, para assim, i) zelar por aqueles que fazem morada na diferença, ii) cuidar da salubridade e do exercício desimpedido das vozes multinaturais num plano de imanência selvagem, sertanejo (não logocêntrico, nem antropocêntrico) (MENEZES, 2018) e iii) combater os processos de assujeitamento dos sujeitos humanos e não-humanos que configuram as constelações cósmicas de nossas malocas, sejam elas da pessoa-indivíduo ou da pessoa-coletivo (CESARINO, 2010). Esta é, sob a mirada do corpo informe, uma tarefa con-temporânea (neoprimitiva).

De partida fica a pergunta fundamental para o texto: o que é ser contemporâneo?

Giorgio Agamben (2009, p. 56-73), em um dos seus seminários sobre o tema da contemporaneidade, indica-nos algumas possibilidades do que quer dizer ser contemporâneo. Inicialmente, ser contemporâneo não está numa relação direta com o atual, nem coincide com este, tão pouco está adequado às pretensões da atualidade. $\mathrm{O}$ atual ou a atualidade - "os dias de hoje" ou "aquilo que se faz presente" - é um resíduo temporal que se particularizou nos planos de possibilidade do tempo, sendo contemporâneo somente na medida em que partilha das tramas do tempo. Em resumo, o contemporâneo é um ser cuja relação com o tempo é inatual.

\footnotetext{
Pertence verdadeiramente ao seu tempo, é verdadeiramente contemporâneo, aquele que não coincide perfeitamente com este, nem está adequado às suas pretensões e é, portanto, nesse sentido inatual; mas, exatamente por isso, exatamente através desse deslocamento e desse anacronismo, ele é capaz, mais do que os outros, de perceber e apreender o seu tempo. [...] contemporâneo é aquele que mantém fixo o olhar no seu tempo, para nele perceber não as luzes, mas o escuro [...] contemporâneo é, justamente, aquele que sabe ver essa obscuridade, que é capaz de escrever mergulhando a pena nas trevas do presente. [...] quem não se deixa cegar pelas luzes do século. [...] ser contemporâneo significa ser capaz não apenas de manter fixo o olhar no escuro da época, mas também de perceber nesse escuro uma luz que, dirigida para nós, distancia-se infinitamente de nós. Ou ainda: ser pontual num compromisso ao qual se pode apenas faltar (AGAMBEN, 2009, p. 55-76).
}

Dentro da notação do contemporâneo habita a palavra do tempo. Contemporâneo é aquele que é e não é o seu presente. Sua ocupação é inatual. Num tempo múltiplo, o contemporâneo é o jogador que observa, participa e mobiliza, com seus lances, as camadas obstruídas da história (tempo humano). Neste jogo gramatical, o contemporâneo espia a 
escuridão dos séculos para perceber nas trevas do presente o "devir negro do mundo" (MBEMBE, 2014, p. 9-22) e mergulhar nesta tinta negra da história sua pena, untando de "negros grammas" as escrituras do agora (Jetzt-Zeit). Sob esta perspectiva, a contemporaneidade delineia os curvos contornos de um tempo, não homogêneo, descontínuo, que atravessa incólume nossos corpos contemporâneos e além, mas que resiste inatual, enquanto memória do que não foi, ao passo que passa e oblitera deixando marcas do não-dito nas transações do atual (quase sempre a narrativa dos vencedores).

A mirada do tempo: ser contemporâneo. Entre um "não mais" pretérito e um "ainda não" futuro, o contemporâneo mantém uma relação especial entre os planos temporais, capaz de "reatualizar qualquer momento do passado" reconstruindo-o e/ou pondo "em relação aquilo que inexoravelmente dividiu", ou ainda, "rechamar, re-evocar e revitalizar aquilo que tinha até mesmo declarado morto" (AGAMBEN, 2009, p. 68-69). Neste sentido, diz-nos Agamben (2009, p. 70), ser contemporâneo é estar na iminência crítica e reconstrutiva de "voltar a um presente em que jamais estivemos" para ler de modo outro a história que se fez inatual, como, por exemplo, a história dos desvalidos - os "sem validade" oficial.

Figura 1: Contemporâneo, ou, $\mathrm{O}$ resíduo diferencial do jogo entre diacronia e sincronia

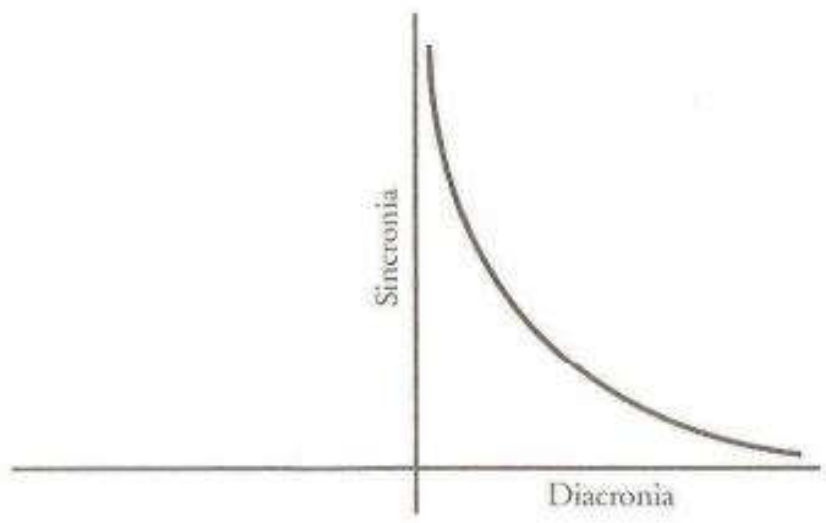

Fonte: Giorgio Agamben (2005, p. 93).

A contemporaneidade é como se o "tempo-agora" (Jetzt-Zeit) da décima quinta tese sobre o conceito de história de Walter Benjamin (1987, p. 230), o "almanaque" que opera como ponto de quebra (- - -) no ciclo serial do livro de ponto (horologium) ${ }^{2}$ do tempo cronológico (-

\footnotetext{
2 "Horologium é o nome que, na tradição oriental, designa significativamente o livro que contém a ordem dos ofícios canônicos segundo as horas do dia e da noite. Em sua forma originária, remonta à ascese monástica palestina e siríaca dos séculos VII e VIII. Os ofícios da oração e da salmodia aparecem aí ordenados como um 'relógio', marcando o ritmo da oração da madrugada (orthros), da manhã (prima, terça, sexta e noa), das vésperas
} 
-). Residual, o contemporâneo é o que urge dentro deste tempo-atual e o transforma: "essa urgência é a intempestividade, o anacronismo que nos permite apreender o nosso tempo" (AGAMBEN, 2009, p. 65-66). Neste sentido, a condição de ser contemporâneo alia-se ao arcaísmo da história, pois "somente quem percebe no mais moderno e recente os índices e as assinaturas do arcaico pode dele ser contemporâneo" (AGAMBEN, 2009, p. 65-66), como o embrião que continua a agir nos tecidos do organismo adulto. $\mathrm{O}$ índice histórico contido nas imagens do passado, desdobradas no presente e lançadas no crepúsculo em direção às outras auroras é o que faz do con-temporâneo um intempestivo. Apresentado num personagem conceitual, o filólogo nietzschiano, o contemporâneo age de "maneira intempestiva - ou seja, contra o tempo, e com isso, no tempo e, esperemos, em favor de um tempo vindouro (NIETZSCHE, 2003, p. 7). Esta é a assinatura que atravessa este texto num intempestivo Brasil à espera de outras auroras e que tem na palavra "balbúrdia" um índice contemporâneo em favor “do amanhã que veio ontem” (SIMAS; RUFINO, 2018). A balbúrdia é o evento que dá voz escritural aos seres informes sufocados nas rasuras do sentido e seus fantasmas nãocontraditórios.

No contemporâneo, entre os refolhos do esquecimento e as entraduras da memória, vive a palavra do tempo. Neste cortejo extemporâneo da contemporaneidade brasileira, o festim deste texto se dá. Seguimos o método de leitura da letra (gramma) benjaminiana, base da história menor (estória): “O método histórico é um método filológico, no qual o livro da vida está na base. 'Ler o que nunca foi escrito' é afirmado em Hoffmannsthal” (apud SELIGMANNSILVA, 2005, p.195-196), nos diz Walter Benjamin. Ler o que nunca foi escrito pelos ofícios fonocêntricos do sentido é ler o livro da vida informe, das existências mínimas (LAPOUJADE, 2017), das humanidades subalternizadas (SPIVAK, 2010). Em termos benjaminianos, trata-se de ler multissensorialmente os "documentos de cultura" produzidos pela "empática história dos vencedores" a partir da urgência dos "documentos de barbárie" sistematicamente sufocados pela narrativa "informacional" do ofício e seus dominadores. Esta é a balbúrdia da "tarefa" da

(lychnikon) e da meia-noite (que, em certas ocasiões, durava a noite inteira: pannychis). Esse cuidado em escandir a vida segundo as horas, em constituir a existência do monge como um horologium vitae [ecce liber, ecce homo], é ainda mais surpreendente quando se considera não apenas o primitivismo dos instrumentos de que eles dispunham, mas também o caráter aproximativo e variável da própria divisão das horas. $\mathrm{O}$ dia e a noite eram divididos em doze partes (horae), desde o ocaso do sol até o alvorecer. As horas não tinham, portanto, como acontece hoje, uma duração fixa de sessenta minutos, mas, com exceção dos equinócios, variavam de acordo com as estações, e as horas diurnas eram mais longas no verão (solstício, chegavam a oitenta minutos) e mais curtas no inverno. Assim, a jornada de oração e trabalho no verão era o dobro daquela do inverno. Além disso, os relógios solares, que são a regra na época, funcionam apenas durante o dia e com céu claro, para o resto do tempo o quadrante é 'cego'. Tanto mais o monge deverá ater-se indefectivelmente à execução de seu ofício" (AGAMBEN, 2014, p. 30-31, grifo nosso). 
sétima tese sobre o conceito de história: "escovar a história a contrapelo" (BENJAMIN, 1987, p. 225). Esta é "a maneira contemporânea" de ler a história: na escuridão e no grande frio onde soam os lamentos da humanidade despojada, conforme a epígrafe de Bertolt Brecht que abre a sétima tese.

Nas rasuras gramaticais das línguas menores (DELEUZE; GUATTARI, 1977), sob a tábula do palimpsesto vital, germina a ocupação do filólogo intempestivo: ler nos corpos e escrever na alma o "quinhão de todas as humanidades subalternas" (MBEMBE, 2014, p. 16). Ao inventariar as vidas informes, o contemporâneo relata o que não acontece no sentido e suas grandes narrativas. Fora-do-sentido (CASSIN, 2017), o gesto contemporâneo encontra-se destinado a "subtrair o único da multiplicidade a ser constituída; escrever a n-1" (DELEUZE; GUATTARI, 1995, p. 21). Voz significante nos planos imanentes da vida, o contemporâneo, em tom menor, alia-se à crítica, "está antes do lado do informe, ou do inacabamento", e os usos da sua gramática "é um caso de devir, sempre inacabado, sempre em via de fazer-se". Portanto, ao invés de afirmar a informação enquanto o "dar a forma a algo" (informo) hermeneuticamente legado pelo pensamento do cânone platônico-aristotélico ocidental, seguimos a linha filológica do informar no tempo do abandono, como "o sem forma" (informis), o fora do sentido sem existência discursiva. Na versão aristotélica, ser informe é possuir um "logos de planta", "não sustentar nenhum discurso", ou seja, segundo Aristóteles (2002, IV, §1006a-1006b, p.145-147), é "não significar uma única coisa [...] pois não se pode pensar em nada sem pensar em algo único". Nesta desclassificada classe dos pensadores do múltiplo estão os marginais, os sem discurso (aneu logon): mulheres, crianças, estrangeiros, bárbaros, monstros, escravos, animais, sofistas... seres informes desvinculados da unicidade do mundo e da uniformidade do sentido.

Desta maneira, anunciamos a nossa balbúrdia textual, o festim dos doces bárbaros que nomeia esta abertura. Giorgio Agamben (2005, p. 79-107) no começo do texto "O país dos brinquedos: reflexões sobre a história e o jogo", dedicado à Claude Lévi-Strauss, fala da "invasão da vida pelo jogo" e de como a incorporação do jogo, do "pandemônio", da "algazarra", da "baderna endiabrada" causa "uma mudança e uma aceleração do tempo", alterando-o e destruindo as pretensões de estabilidade, dilatando-o numa "utópica república" que subverte as ordens sociais, suspendendo a sucessão dos dias, fazendo das horas, lampejos, num efeito paralisante assemelhado com o do brincar e da festa. Este é o efeito da balbúrdia, ao qual amaldiçoa o Ministro da Educação.

Agamben cita alguns exemplos dessa cooptação da vida pelo jogo e seu caractere festivo, todavia, ponho em relevo o que retira do Ramo de Ouro de James Frazer (1931, p. 411). O Calluinn era uma antiga festa escocesa, realizada no último dia do ano, em que rapazes 
vozeantes e vestidos com peles de animais, provavelmente vacas, imitavam o curso do Sol, ao voltearem as casas, com a finalidade de afastar os infortúnios e assegurar a regeneração do tempo. Este dia representa o significante instável do tempo (con-temporâneo). Entre a continuação do passado e advento do futuro, os antepassados mortos e os adultos vivos, o Calluinn ou Challuinn, que pode representar Ano Novo (Hogmanay, passagem de ano escocês), mas também quer dizer em gaélico escocês "informe", "desforme" ou "deformado", é o simbólico dia festivo das larvas e das crianças, em que entre o último dia de dezembro e o primeiro de janeiro, se estabelece um limiar entre as marcações do tempo, o amanhã e o ontem, onde "brincando, o homem desprende-se do tempo sagrado e o 'esquece' no tempo humano", faz-se história. Este dia informe (Calluinn) não é "nada mais que jogo", um dia qualquer no "país dos brinquedos", como nos apresenta Carlo Collodi (2014, p. 190-191) no capítulo 31 das Aventuras de Pinóquio replicado por Agamben (2005, p. 81).

\begin{abstract}
O país não se parecia com nenhum outro do mundo. A população era formada apenas de crianças. O mais velho deles tinha catorze anos e o mais jovem não chegava a oito. Pelas ruas uma alegria, um alvoroço, um alarido de endoidecer! Bandos de moleques por toda parte: aqui se jogava birosca, ali malha, mais além bola; alguns andavam de velocípede, outros de cavalinho de pau; uns brincavam de cabra-cega, outros de esconde-esconde; uns, vestidos de palhaços, brincavam de engolir fogo; outros recitavam, cantavam, davam saltos-mortais; aqui se divertia em andar com as mãos no chão e com as pernas para o ar; ou se rodava arco, passeava-se vestido de general com um elmo de papel e o espadão de cartolina; aqui se ria, ali se gritava, além se chamava, batiam-se palmas, assoviava-se, imitava-se o som da galinha botando ovo: em suma um tal pandemônio, um tal vozerio, uma tal balbúrdia endiabrada de se meter algodões nos ouvidos para não se ficar surdo. Em todas as praças, teatrinhos de lona, repletos de meninos da manhã à noite, e em todos os muros das casas viam-se escritas a carvão coisas belíssimas como estas: "queremo us brinquedo", "abacho a escola", "xega de deveris" e outras pérolas do gênero.
\end{abstract}

Num dia informe, como o Calluinn, brota o festim dos doces bárbaros. Na festa, signo das transformações estruturais, das misturas dos papéis sociais, da instauração da história ao avesso, eclodem os Doces Bárbaros, paradoxal ligadura entre a docilidade dos "corpos disciplinados" pela fala articulada dos portadores do logos e a algaravia dos barbarismos da fala marginal e informe. Nesta deglutição antropofágica o que nasce é uma fala híbrida, nem singelamente manipulável e dócil - "é dócil um corpo que pode ser submetido, que pode ser utilizado, que pode ser transformado e aperfeiçoado" (FOUCAULT, 2011, p. 132) -, nem ininteligível e inapta como a fala selvagem. A fala híbrida é maculada pela palavra selvagem, provocadora do alongamento significativo dos planos de imanência da vida. Os Doces Bárbaros transitam no descompasso do mundo ordeiro, no balbucio inarticulado da fala civilizada. Como diz a música da epígrafe, atravessando os grossos portões invadem a cidade amada e acessam a "cidade velha" do logos. Na antiga pólis, já, desde então diversa (“outra cidade velha"), os doces bárbaros - contemporâneos das auroras do ontem - ao dulcificarem sua barbárie com o 
tempero da fala, jogaram "com amor no coração" e "cheios de felicidade" a pólis amarga e séria (spoudé) do sentido único (logos-phoné) nas balbúrdias dos múltiplos significados das ruas, becos, guetos e vielas que gaguejam soluçantes o tropel linguístico dos seres informes. A pulular humanidades nas cirandas de exceção da história, "os mais doces bárbaros" furam a norma da pólis, tingem seu espírito político e, como é típico aos bárbaros e comensais informes, maculam o logeion disposto para a fala plena ao, num ato de desobediência civil, falarem, emitirem um discurso (um outro sentido) que convulsiona a língua daqueles outrora privilegiados com o poder da fala, borrando assim os limites da humanidade e seus etéreos dilemas entre natureza e cultura.

Figura 2: "Nossos planos são muito bons".

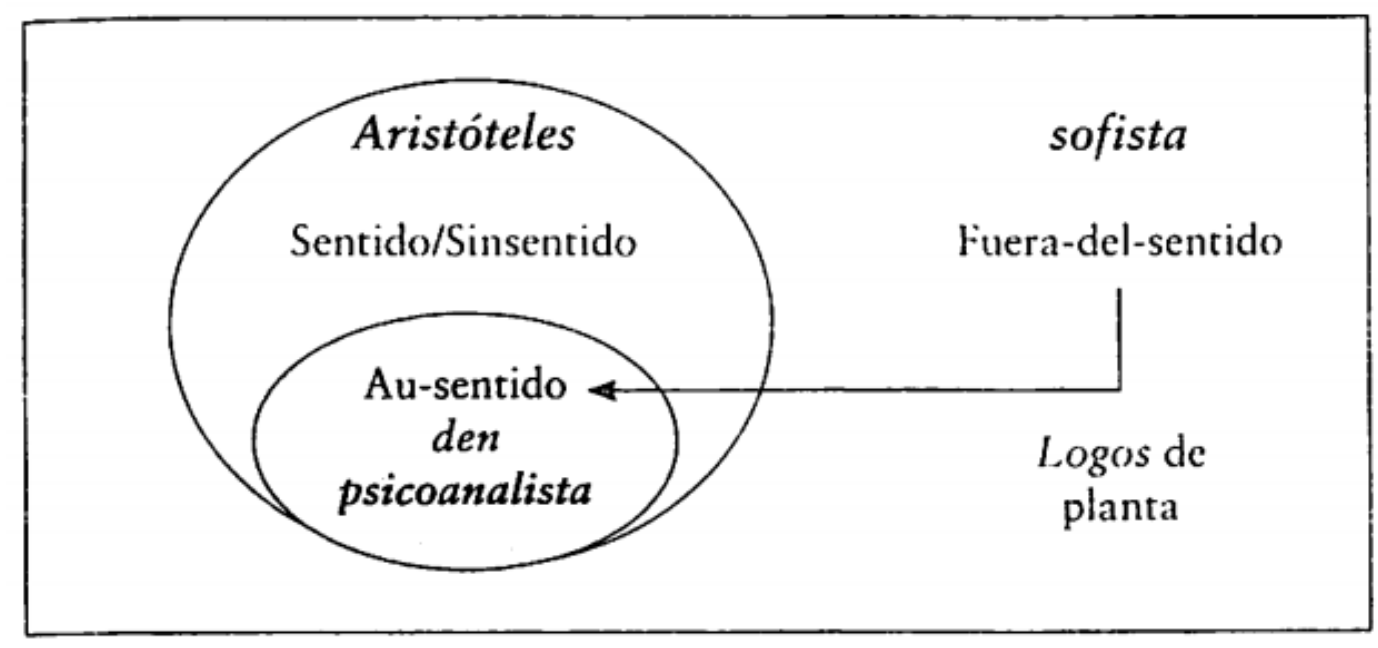

Fonte: Barbara Cassin (2017, p. 166). 


\section{PÁSSAROS PROIBIDOS}

Solto está o pássaro proibido Perigo, cuidado, sinal nas ruas

[...] Pássaro proibido de sonhar O canto macio, olhos molhados Sem medo do erro maldito

De ser um pássaro proibido Mas com o poder de voar

[...] Eu canto o sonho na cama Do jeito doce e moreno

Eu canto

Voar até a mais alta árvore Sem medo, tranquilo, iluminado

Cantando o que quer dizer Perguntando o que quer dizer $\mathrm{O}$ que quer dizer meu cantar.

Pássaro proibido - Maria Bethânia e Caetano Veloso (1976)

Os "pássaros proibidos" são uma metáfora dos seres informes - soltos, com o poder de voar e a capacidade de sonhar, distantes do erro maldito, libertos no cantar. Em termos de contexto, essa escritura baseia-se em alguns pensadores, uns mais escolares, outros mais transgressivos, contudo, os personagens convocados ao debate estão sob a constelação estéticomusical dos Doces Bárbaros, a saber, em ordem alfabética: Caetano Veloso, Gal Costa, Gilberto Gil e Maria Bethânia. Os Doces Bárbaros além do significado simbólico já expresso, foi/é um grupo de brasileiros, nascidos na Bahia, que se juntaram em 1976 para uma espécie de Calluinn, uma aventura coletiva para a celebração de trajetórias individuais. As circunstâncias para esta formação são exemplares para o propósito deste texto - o modus operandi da cultura de exceção - e suas relações com a balbúrdia e o tropel dos seres informes configuram uma linha de ação fértil para os avanços sistêmicos do governo brasileiro contra a educação, emoldura sob o signo da balbúrdia.

Os Doces Bárbaros nascem em um Brasil governado pelo regime militar, orientado pela violência e a repressão às vozes dissidentes ao governo, que anos antes à formação tinha mandado ao exílio dois dos quatro componentes (Caetano Veloso e Gilberto Gil). Os quatro seres elementais dos Doces Bárbaros são vinculados ao desbunde da possibilidade possuída por todos de tornar-se outro. Eram associados às vanguardas artísticas, à antropofagia, à contracultura, ao tropicalismo, à bossa nova, ao cinema novo, ao movimento Hippie e outras 
efervescências da década de 1960 que tinham nos anos 1970 seus desdobramentos e inovações sob o signo da liberdade. Toda uma tropelia de movimentos transgressivos encontrava-se associada aos Doces Bárbaros, seres informes em busca do "que quer dizer" os múltiplos modos de "dizeres" - cantado, falado, discursivo, poético etc. Na contramão da repressão, os Doces Bárbaros foram insistentemente fustigados e coibidos pelos "seres informados" que ditavam o "capital cultural" brasileiro, espécie derivada do meta-capital informacional do Estado (BOURDIEU, 2008). Entretanto foi o jornal satírico O Pasquim que reservou aos baianos a alcunha da barbárie (BENJAMIN, 1987). É desta última manifestação que nasce o motivo da nomeação do grupo como Doces Bárbaros.

O Pasquim foi um semanário alternativo e sucesso editorial surgido em 1969, de resistência ao regime militar e viés satírico-subversivo, com figuras importantes do movimento intelectual brasileiro de oposição à ditadura. Em 1971, com a mudança de editoria e a ascensão de Millôr Fernandes ao cargo de chefia na redação, O Pasquim abriu uma campanha de estigmatização contra os baianos, em especial, Caetano Veloso e Gilberto Gil - sendo desde então chamados de "baihunos" (NUNES, 2016, p. 113).

Na edição número 141 de 14 de março de 1972, uma charge de Ziraldo, sob o título "Ziraldo e a invasão", mostrava as areias da praia de Ipanema absolutamente preenchidas de gente, sem um único espaço vazio. Um dos personagens diz: "Essa praia era uma beleza antes da invasão dos baihunos" (ZIRALDO, 1972, p. 10). Ao fundo do desenho, uma grande armação de ferro e madeira que avançava mar adentro, assinalava a construção de um emissário submarino - obra que durou de 1970-1973. Este local da representação bárbara de Ziraldo foi ponto de encontro para surfistas, artistas e "desbundados" em geral (CASTRO, 1999, p. 296297). A ágora da "esquerda festiva” da Zona Sul do Rio de Janeiro fora invadida pelos bárbaros e cabeludos da esquerda libertina da Bahia; a "patota" ipanemense queixava-se da ocupação e nomeava a "horda" forasteira - conforme representação de Ziraldo - de "baihunos". Contudo, Ziraldo somente tornou público o repúdio compartilhado por membros da redação d'O Pasquim e fez do neologismo cunhado por Millôr Fernandes o termo de ataque, como relatado por Jaguar quando diz: "Do Rio pra cima e do Rio pra baixo, ele [Millôr] era totalmente intolerante e comprou uma briga séria com o pessoal do Norte. Ele falou uma vez, numa crônica: 'Essa gente nordestina'...” (NUNES, 2016, p. 120). 
Figura 3: Ziraldo e a invasão

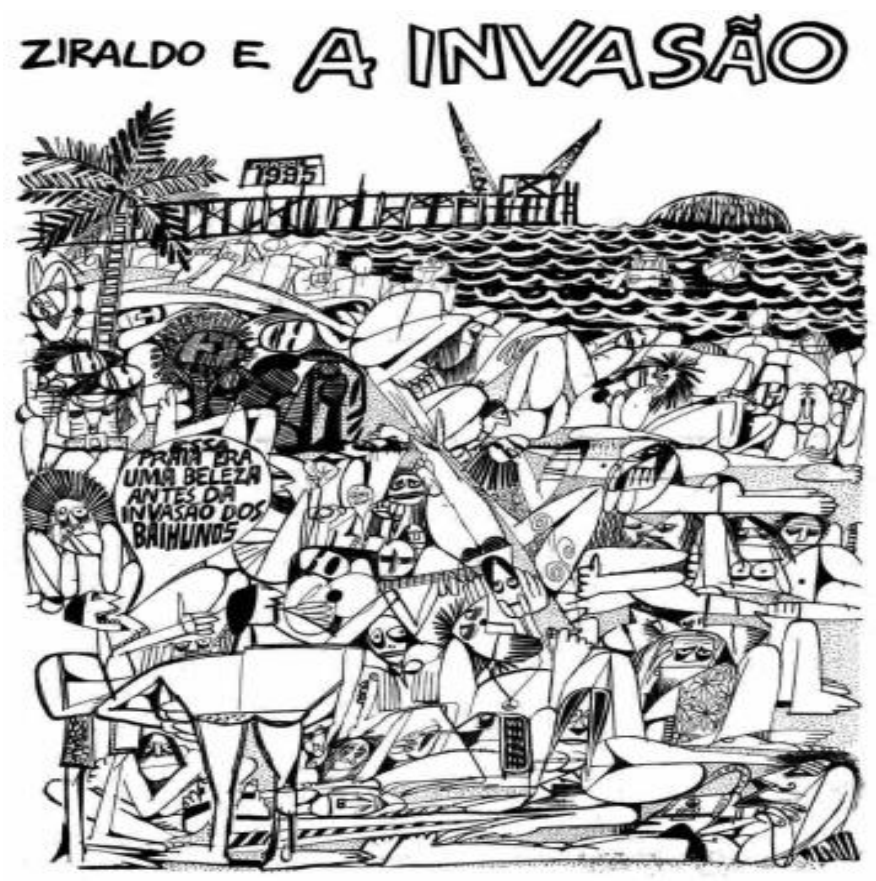

Fonte: Ziraldo (1972, p. 10).

Jorge Mautner, um dos mais atacados por Millôr Fernandes, classificou como "totalmente racismo" os ataques promovidos pelo chefe d'O Pasquim (NUNES, 2016, p. 123).

[...] como o sentimento do Millôr era muito conservador, muito reacionário, ele odiava a contracultura, o tropicalismo, todas essas manifestações juvenis e libertárias da época. Ele detestava e contaminava os outros com esse ponto de vista. Ele foi o responsável pela cisão que houve, porque ele respeitava que os outros escrevessem tudo, menos aquela 'merda', como ele disse uma vez, de maciéis, caetanos e jorge mautners e não sei o quê. Ele detestava isso tudo. Achava um bando de débeis mentais, maluquinhos, maluquetes. Então, aí os outros embarcaram na canoa dele. Baihunos foi uma ideia do Ziraldo, mas do Ziraldo já enfeitiçado pelo Millôr (MACIEL apud NUNES, 2016, p. 116).

Em seu livro Geração em transe: memórias do tempo do tropicalismo, o jornalista e filósofo Luiz Carlos Maciel (1996), ex-colaborador d'O Pasquim, atribuiu a criação do termo "baihunos" ao humorista Millôr Fernandes. Segundo Maciel (1996, p. 240), o objetivo era “comparar os cabeludos a bárbaros de algum tipo". Logo, associou a palavra baiano à palavra "hunos", um conjunto de tribos nômades euroasiáticas, que se moveram para a Europa Ocidental por volta do século IV depois do Cristo e que travaram no século V sucessivas batalhas que selaram o declínio do Império Romano do Ocidente. Simbolicamente, os Hunos legaram para o imaginário civilizacional eurocêntrico greco-latino o estatuto por excelência de "bárbaros". A título de exemplo, a Encyclopedia of First World War apresenta como o termo "hunos" foi utilizado pela propaganda da Aliança, em especial pelos britânicos e 
estadunidenses, para designar os inimigos alemães. Durante a Segunda Guerra Mundial este uso voltou a ser atribuído aos inimigos.

Figura 4: Propagandas da Aliança durante a $1^{\text {a }}$ Guerra Mundial contra os "hunos" (alemães).

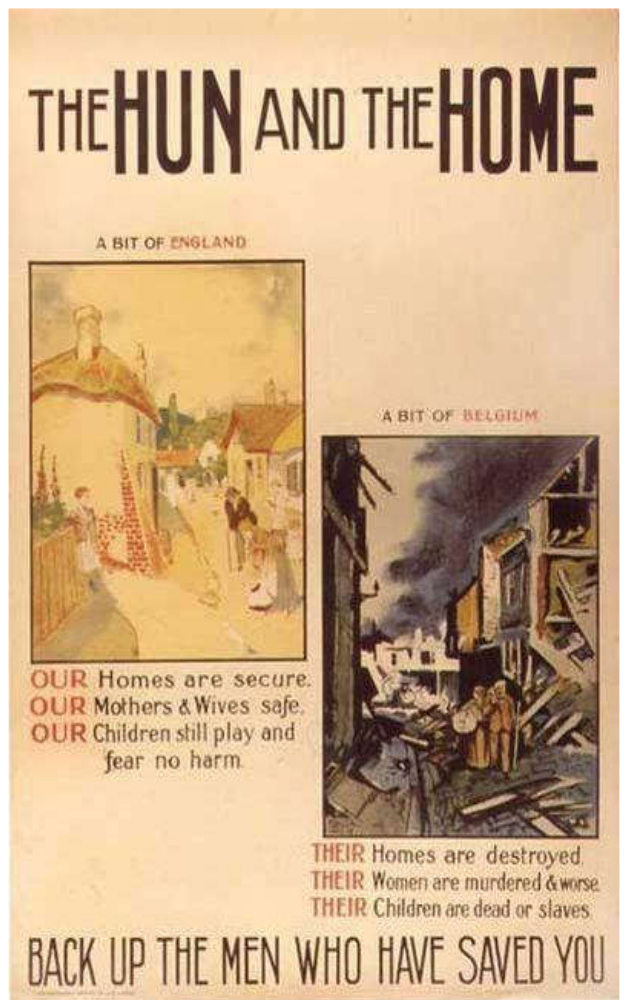

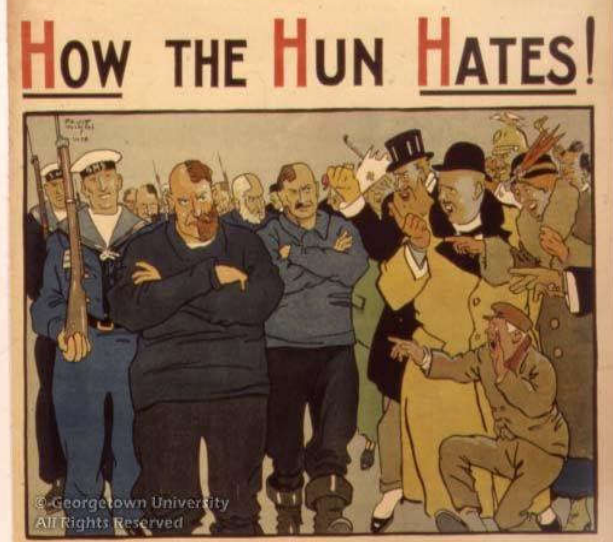

THE HUNS CAPTURED SOME OF OUR FISHERMEN IN THE NORTH SEA AND TOOK THEM TO SENNELAGER. THEY CHARCED THEM WITHOUTASHRED OF EVIDENCE WITH BEINC"MINE LAYERS.THEY ORDERED THEMTO BE PUNISHED WITHOUT A TRIAL.

THAT PUNISHMENT CONSISTED IN SHAVING ALL THE HAIR OFF ONE SIDE OF THE HEAD AND FACE.

THE HUNS THEN MARCHED THEIR VICTIMS THROUCH THESTREETS AND EXPOSED THEM TO THE JEERS OF THE GERMAN POPULACE.

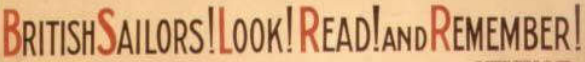

Fonte: Michael Duffy (2009).

Perante este clássico "outro" - inimigo e bárbaro -, o poder midiático de nomeação d'O Pasquim cunhou o termo "baihunos" com a função de designar os baianos como "bárbaros", "invasores" do reduto carioca da Zona Sul - território classificado por muitos moradores como "umbigo do mundo". Jorge Mautner, que também teve seus embates com O Pasquim e conviveu com os "baihunos" no exílio, conta em entrevista (NUNES, 2016, p. 177), que às vésperas da união dos quatro baianos para a turnê em 1976, ele sugeriu satirizar paradoxalmente a alcunha racista de "baihunos" ao propor o oximoro: "doces bárbaros". De acordo com Mautner, ele disse para os baianos: “ah, mas vocês ficam impressionados? Jesus não era um 'doce bárbaro'? Daí que fizeram o nome 'doces bárbaros'." Pássaro proibido, Jesus, agente espiritual subversivo, foi essa figura ambivalente, ambígua, equívoca, a um só tempo, mundano e extramundano, sagrado e profano, doce e bárbaro, portador de uma fala libertária, todavia forasteira, mas que em sua blateração bárbara subverteu docemente corações imperiais. 
Os Doces Bárbaros são pássaros proibidos. Em seus voos transpõem as barreiras das Formas (eidos), trespassam os limites do Mesmo, as fronteiras da consciência. Signo movente, o pássaro é um símbolo do interdito em governos autoritários, afeiçoados às sopas (alegoria latino-americana dos regimes militares). Como a origem latina da palavra expressa, "pássaro" vem de passer(e), "pardal”, cuja raiz vem de passus e do verbo transitivo pando(ere). Passus significa passar, atravessar, transpor; na retórica clássica, simboliza o impróprio uso da linguagem, a metáfora (NIETZSCHE, 2000). Em sentido coletivo, passus significa "aquilo" que se espalha, se estende, aqui e ali, de todos os lados, em todas as direções, sem distinção, hibridamente. Passare é, por exemplo, o canto dos estorninhos, que "voam em bando, enchendo o céu de estridos e de rumores", como metaforizou Galileu Galilei em $O$ ensaiador (MARICONDA; LACEY, 2001, p. 52). Enquanto particípio de pandere, passus denomina o ato de (des)dobrar, perfurar, trespassar, transfixar, abrir afastando, como, por exemplo, na sentença latina que muito nos diz: moenia urbis pandere - "fazer uma brecha nas muralhas da

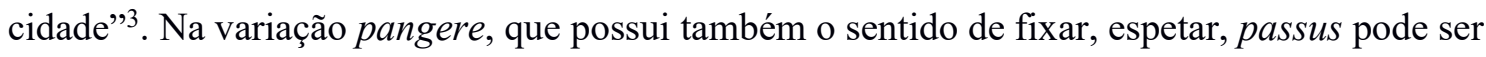
lido como o ato de gravar na cera, de compor e escrever. Todavia, trata-se de uma fixação alada, móvel, como no sentido de volucer, a ave marcada pela inconstância, pelo voo fugidio, efêmero, enfim, pelo signo da abertura e da passagem.

Ainda sobre o signo do pássaro, Claude Lévi-Strauss em suas Mitológicas, em especial A oleira ciumenta (1986), livro chave para a paisagem do pensamento ameríndio e a interpretação da "fórmula canônica do mito" (ALMEIDA, 2008), assinala, a partir de um mito Jivaro, o papel dos pássaros Engolevento (Bacurau, dentre outros nomes) e João-de-Barro na formulação mítica Jivaro; estes pássaros estão diretamente relacionados aos temas “informes/amorfos" da cerâmica e do ciúme (LÉVI-STRAUSS, 1986, p. 28-29), questões fundamentais de formação e ordenamento de sentido no mundo da família linguística Jivaro. Leo-Strauss através da simbolização narrativa dos pássaros aponta para estes como símbolos imprescindíveis para a "dupla torção" interpretativa dos mitos em seus saltos descontínuos e suas transformações sucessivas e abertas. Os pássaros da fórmula mítica Jivaro marcam um dos caracteres mais peculiares do pensamento ameríndio: a transformação/metamorfose, ou, o "desequilíbrio perpétuo" que define a transformação estrutural por excelência nas sociedades ameríndias. Marcados pela "inconstância da alma selvagem" (CASTRO, 2002), os "pássaros proibidos" são a insígnia do bárbaro, do selvagem amorfo cuja força "consiste em poder

${ }_{3}$ Pandana era como se chamava uma das portas, sempre aberta, da antiga Roma. 
transpor as fronteiras da experiência sensível e se projetar rumo ao desconhecido" (ALMEIDA, 2008, p. 178).

Os Doces Bárbaros são pássaros selvagens, bardos de um cântico proibido à fixidez das estruturas civilizacionais. Festivos e brincantes, trovam o Calluinn ante o "perigo, o cuidado e o sinal nas ruas". O pássaro proibido é a metáfora dos seres informes, privados da fala luminosa carregada de sentido. Contrapostos à consciência da razão esclarecida, sonham de um "jeito doce e moreno" o inconsciente questionador e decisivo do "que quer dizer" a sua expressão. A barbárie que os Doces Bárbaros evocam urge dos guetos como alternativa contracultural ("documentos de barbárie") à cultura ditatorial instaurada da censura da fala, do calar-se do adverso, da mudez do estranho estrangeiro (apátrida). Ao dulcificarem a bárbara fala, os Doces Bárbaros fissuram as muralhas da cidade e voam poeticamente para fora dos flancos da fala única entalhados na "máquina antropológica" do pensamento ocidental (AGAMBEN, 2011). Humanizam-se. A balbúrdia desse ato poético “é voar fora da asa” (BARROS, 2013, p. 302).

\section{BALBÚRDIA, A SELVAGEM PALAVRA QUE GAGUEJA A LÍNGUA}

Achava que a partir de ser inseto o homem poderia entender melhor a metafísica. Eu precisava de ficar pregado nas coisas vegetalmente e achar o que não procurava. [...] Caminhei sobre grotas e lajes de urubus. Vi outonos mantidos por cigarras. Vi lamas fascinando borboletas. E aquelas permanências nos relentos faziam-me alcançar os deslimites do Ser. Meu verbo adquiriu espessura de gosma. Fui adotado em lodo. Já se viam

vestígios de mim nos lagartos. Todas as minhas palavras já estavam consagradas de pedras. Dobravam-se lírios para os meus tropos. Penso que essa viagem me socorreu a pássaros. Não era mais a denúncia das palavras que me importava mas a parte selvagem delas, os seus refolhos, as suas entraduras. Foi então que comecei a lecionar andorinhas.

Manoel de Barros (2013, p. 323-324), O livro das ignorãças, III $^{\mathrm{a}}$ parte: Mundo Pequeno

"Balbúrdia" é a palavra-classificadora utilizada pelo atual Ministro da Educação, em 30 de abril de 2019, para significar o desprezo pela atividade universitária brasileira. O ministro fundamenta a universidade pública como antro de balbúrdia e baseia nesta acusação a decisão para os primeiros grandes cortes orçamentários da educação superior brasileira, como dito em entrevista ao jornal Estado de São Paulo (AGOSTINI, 2019): "MEC cortará verba de universidade por balbúrdia". Por balbúrdia, o Ministro refere-se à "bagunça, evento ridículo, festa, arruaça, seminários absurdos" e baixo "desempenho acadêmico". Como exemplo de 
"bagunça" diz: "sem-terra e gente pelada dentro do campus". Vale lembrar que Jair Bolsonaro, atual Presidente da República, em 18 de setembro de 2015, quando exercia a função de deputado federal, em entrevista ao Jornal Opção (VITOR, 2015) afirmou que caso as Forças Armadas brasileiras diminuíssem o efetivo seria "menos gente nas ruas para fazer frente aos marginais do MST, dos haitianos, senegaleses, bolivianos e tudo que é escória do mundo que, agora, está chegando os sírios também. A escória do mundo está chegando ao Brasil”. O que a fala do atual Presidente tem em comum com a fala do então Ministro da Educação é o racismo. Na última Pesquisa do Perfil Socioeconômico dos Estudantes de Graduação das Universidades Federais, publicada em 2018 pela Andifes (Associação Nacional dos Dirigentes das Instituições Federais de Ensino Superior), os dados apontam uma realidade indigesta para o espírito etnocêntrico do atual governo: a "escória do mundo", ou seja, alunos negros, de baixa renda, que estudaram em escola pública, com renda familiar de até um salário mínimo e meio e que tem pais que não fizeram faculdade são maioria nas universidades públicas e federais brasileiras.

Sem fundamentação, registro fidedigno ou qualquer tipo de pesquisa comprobatória, que por ora dizem o contrário, com as universidades públicas brasileiras aparecendo entre as melhores ranqueadas na América Latina e no Mundo - como reporta a própria matéria citando o ranque Times Higher Education (THE) -, o Ministro acessa o imaginário discriminatório da máquina antropológica do pensamento ocidental, e frente aos interesses da agenda conservadora do governo em curso, classifica seus adversários/inimigos como promotores de "balbúrdia", isto é, bárbaros, espécime social do homo alalus (humano sem fala). Perguntado sobre se tal ato não se assemelhava com uma "lei da mordaça", o então Ministro afirma que "todos têm logicamente o direito de se expressar, desde que o desempenho acadêmico esteja bom". Segundo o ministro, sem nenhum critério ou pesquisa de fundamento, está "ruim". Logo, nestes termos, aos olhos do ministro, a comunidade acadêmica não deve se expressar, deve calar-se frente o suposto mau desempenho, que mais parece fruto do desejo de extermínio do ministro, do que propriamente o que ocorre segundo os indicadores nacionais e internacionais de avaliação da produção acadêmico-científica.

Após o primeiro anúncio de cortes vieram outros cortes disfarçados de "contingenciamentos", atualmente contabilizados em mais ou menos 2,2 bilhões de reais. Desses bilhões, um total de 926 milhões de reais foram destinados, segundo o próprio Ministro da Educação, para "pagar emendas" aos parlamentares que votaram com o governo pela aprovação da Reforma da Previdência, conforme reportagem do dia 16 de agosto de 2019 da Folha de São Paulo (SALDAÑA, 2019). Em outras palavras, sob o signo da balbúrdia, o 
investimento público na Educação brasileira foi interrompido e destinado para a "compra de votos" de parlamentares, aparentemente incapazes de exercerem suas funções públicas e julgarem politicamente, por meio do interesse público e do bem comum a todos, se uma pauta qualquer, como o caso da Reforma da Previdência, é positiva ou não para o povo que representa.

Deste modo, a temática da balbúrdia linguisticamente se insere neste texto. Uma urdidura que se inicia como uma fala contemporânea acerca do Brasil. Sendo teoricamente posto i) o que significa, para nós, "ser contemporâneo", ii) como a contemporaneidade, a partir dos seus resíduos diferenciais e suas transformações estruturais, deixa-nos próximos interpretativamente de significantes instáveis, que, por sua vez, que conectam-se iii) aos conjuntos profanos dos jogos que rearranjam e alteram as configurações sociais e feito "um virar de pedras", onde acessamos e somos acessados por um mundo ao avesso, de "povos menores" que se escondem por debaixo delas (insetos, larvas, vermes, mulheres, crianças, estrangeiros, homossexuais, etc.). Ao revelar o humo das vidas soterradas, o menor faz nosso "verbo adquirir espessura de gosma", "nossas palavras consagrar-se de pedras", "nossos tropos dobrar-se em lírios". Por uma balbúrdia qualquer, vidas informes brotam num dia amorfo, pulsam no avesso do tempo.

Sob a perspectiva dos "povos menores" (DELEUZE, 1997, p. 14), este mundo bárbaro tem na travessia profana da composição semântica dos Doces Bárbaros sua expressão exemplificada na facticidade discriminatória da alcunha de "baihunos" e na metáfora propositiva do pássaro proibido. Os Doces Bárbaros é o exemplo adotado por ter a característica ambivalente de agregar sob um mesmo espectro significativo, o símbolo civilizacional do controle da ordem social, da polidez das maneiras, da aquietação dos ânimos do "corpo dulcificado" e o selo inconstante das variações do "corpo selvagem". A balbúrdia é o evento que talvez torne possível essa "síntese disruptiva" (DELEUZE; GUATTARI, 1992, p.82), o despertar da parte selvagem da linguagem que gagueja a língua e faz-se discurso. Balbúrdia é o acontecimento (calluinn) onde os seres informes, em seu tropel, confundem os limites do humano e balbuciam a humanidade por meio dos seus pontos de vista. A pólis passa a ser qualquer lugar onde a vida encante - um "lugar não-onde", segundo Guimarães Rosa (2006, p. 38), ou como designado por Platão no Timeu (1992, §51a), um lugar informe onde se hospedam os discursos (pandekhês), ao que e para quem o informe dá lugar, faz falar.

Portanto, a balbúrdia é um vozerio que marca a condição passageira e incondicionada dos seres informes na linguagem. É incondicionada pela abertura da palavra à uma humanidade disseminada. Arrebatados pela palavra, arrebentam as barreiras do discurso, não para conformar-se com o "sentido normativo" da não-contradição, nem para reproduzir impondo a 
fala estrangeira, porém para destinar um espaço às "outras palavras" não-acontecidas no mundo antropocêntrico.

Balbúrdia é uma palavra que advém da contração de balbus com a terminação pejorativa de origem popular e obscura -úrdia. Balbus é aquele que fala obscura e confusamente, de modo inarticulado ou com hesitação, balbuciando. A rigor, trata-se do gago (balbus), mas também do barbarus, isto é, de todos os povos, salvo os gregos e romanos. Barbarus são os povos incultos, selvagens (não-gregos, não-latinos). Os Balbus, à maneira dos estrangeiros, falam com erros e rudeza (barbare loqui). Como assinalado por Bittencourt e Lopes (2008, p. 97), balbus é possivelmente "a raiz etimológica de bárbaro", onde, "balbus, em latim, é gago e a lógica da relação dominados/dominantes no que se refere à questão linguística é exatamente esta: o outro é inferior porque não sabe falar, gagueja sons inarticulados, sem sentido claro." Como é recorrente, na tradição ocidental, o "próprio do homem", o que o desarticula do animal é a linguagem. Ser humano é falar articuladamente. Logo, o antropos é a condição de poder falar a língua dominante (grego ou latim, no mundo clássico) e ascender à humanidade. O que está para além ou aquém deste limite é inumano.

O mecanismo de exclusão etnocêntrica traduz a "fala" para os seres desprovidos de linguagem por meio de palavras como "gritar", "urrar", "cantar", "soprar" e mesmo "gaguejar". São estas sinonímias de balbus e, por sua vez, de barbarus. Derrida (2013, p. 152) argumenta que nas línguas mais antigas do indo-europeu, as palavras que servem para designar a alteridade e os povos estrangeiros provêm de duas fontes: ou dos verbos que significam "gaguejar", "balbuciar", ou das palavras que remetem à "mudez" e ao sem-voz (in-fans - infầncia). Barbara Cassin (2018, p. 288) no Dicionário dos intraduziveis: um vocabulário das filosofias, que coordena, em certa altura do texto faz uma pergunta chave para nós: “que é um 'bárbaro' para um grego?" Cassin, a bárbara, diz que héllen (grego) e barbarus são antônimos assimétricos; enquanto hellenizein constitui um cabeçalho que agrega os sentidos de "falar grego" e "falar corretamente", cujo corpus histórico-político implica uma questão de gênero, ou seja, helenizar-se significa "se comportar como homem livre, civilizado e culto - numa palavra: como homem" (CASSIN, 2018, p. 287), por outro lado, a onomatopeia barbarizein designa uma conjunção de traços linguísticos, antropológicos e políticos que fazem do bárbaro um héteros, um "inteiramente outro de si, ininteligível, e cuja humanidade mesma poder ser posta em questão" (CASSIN, 2018, p. 288). No campo retórico-gramatical, o barbarismo, tecnicamente um desdobramento de uma balbúrdia linguística (barbarolexis), designa um efeito de ininteligibilidade, declinado dos usos de expressões estrangeiras. Perante o afastamento do sentido próprio e do uso corrente da linguagem, os barbarismos são associados à linguagem 
figurada e às metáforas, pois embaralham os significados, causam interferências nos significantes e frente aos empréstimos linguísticos, fazem da linguagem um enigma, conforme diz Aristóteles na Poética $(2008, \S 1458 \mathrm{a}, 18-31)$. O problema para o mundo grego, que persiste até os dias atuais, é determinar se a barbárie é um fato de natureza ou de cultura. Este problema é categorizado por Aristóteles como uma querela política fundada na insígnia da escravidão, clamada pelos bárbaros, que segundo o Estagirita, anseiam pelo despotismo: "os bárbaros são por natureza mais escravos que os gregos" $(1998, \S 1285 \mathrm{a}, 20)$. Sob este ponto de vista sigético, da supressão da voz, os bárbaros murmuram com a boca fechada (*mu) a máquina antropológica ocidental que "transforma a linguagem humana em língua pré-babélica, a história em natureza" (AGAMBEN, 2005, p. 76).

Perante este tecido de significados de balbus, resta-nos analisar a terminação de origem popular -úrdia, que associados geram a palavra balbúrdia. Cabe dizer que a composição de úrdia à palavra balbus é quase um pleonasmo. Poucas palavras na língua portuguesa possuem tal terminação, todavia, às que possuem, estão todas relacionadas à mácula negativa de significação de balbus. Estapafúrdio, estúrdio, palúrdio, balúrdio e balbúrdia são as palavras da língua portuguesa terminadas na partícula -úrdia. Estapafúrdio significa algo bizarro, excêntrico, pessoa disparatada, não lógica (fora dos princípios de não-contradição), incoerente. Estúrdio quer dizer algo similar, pessoa desajuizada, pândega, que leva uma vida leviana. Palúrdio é o tolo, sem inteligência e incapaz de discernir. Por fim, balúrdio é uma palavra usada na linguagem de delinquentes para a falsificação de dinheiro; balúrdio é também conhecido como paco, palavra advinda das gírias dos subúrbios de Buenos Aires, muito usada pelos tipos marginalizados e pelos tangos. A palavra paco vem de um exemplo de barbarismo que se emancipou e adquiriu vida própria - força de uso. Paco é uma palavra lunfarda, dialeto praticado na Argentina e no Uruguai, originado da miscigenação entre as línguas locais, inclusive as diaspóricas, com as línguas dos imigrantes europeus, em especial os italianos, que se fixaram nas periferias de Buenos Aires. A própria palavra "Lunfardo" aparece como uma possível corruptela etimológica de Lombardo e supõe-se que surgiu como um tentativa de ocultação de significado criada pelos prisioneiros para não serem entendidos pelos carcereiros. Uma das características do Lunfardo é a inversão da linguagem através da alteração da ordem das sílabas das palavras. Este falar ao avesso é encontrado em letras de tango (gotán, em Lunfardo), sendo muitas vezes empregados no despertar da ambivalência e do duplo sentido das letras, em geral, vinculado às temáticas marginais: sexo, drogas, submundo, criminalidade. O Lunfardo é empregado pelo falante para demarcar a oposição do seu lugar de fala ao falar genérico, culto e normativo. 
Desta maneira, o Lunfardo guarda consigo a memória de uma balbúrdia linguística, o balbus ou barbarus como personagens conceituais da alteridade dissidente que ingressam no balbuciar da infância (infans) de modo inverso ao silêncio obliterante da tradição helênica: "a infância é precisamente a máquina contrária, que transforma a pura língua pré-babélica em discurso humano, a natureza em história" (AGAMBEN, 2005, p. 76). A balbúrdia é o evento infantil de passagem da mudez natural à cultura multinatural: "por esta razão, enquanto o homem, no conto de fadas, emudece, os animais saem da pura língua da natureza e falam" (AGAMBEN, 2005, p. 78).

Os personagens conceituais aqui acionados, frente a balbúrdia, não mais gaguejam numa língua, "gaguejam toda a linguagem"; movem-se por entre os planos de imanência da vida, povos menores, andarilhos que em seus levantes provocam um tropel, fazendo "da gagueira o traço do próprio pensamento enquanto linguagem" (DELEUZE; GUATTARI, 1992, p. 84). Doces Bárbaros, "a lecionar andorinhas".

O escritor se serve de palavras, mas criando uma sintaxe que as introduz na sensação, e que faz gaguejar a língua corrente, ou tremer, ou gritar, ou mesmo cantar: é o estilo, o ‘tom', a linguagem das sensações ou a língua estrangeira na língua, a que solicita um povo por vir, oh! gente do velho Catawba, oh! gente de Yoknapatawpha! O escritor torce a linguagem, fá-la vibrar, abraça-a, fende-a, para arrancar o percepto das percepções, o afecto das afecções, a sensação da opinião — visando, esperamos, esse povo que ainda não existe. 'Minha memória não é amor, mas hostilidade, e ela trabalha não para reproduzir, mas para descartar o passado... Que queria dizer minha família? eu não sei. Ela era gagá de nascença e contudo tinha algo para dizer. Sobre mim, e sobre muitos de meus contemporâneos, pesa a gagueira de nascença. Aprendemos, não a falar, mas a balbuciar, e é só ouvindo o ruído crescente do século, e uma vez lavados pela espuma de sua onda mais alta, que nós adquirimos uma língua'. (DELEUZE; GUATTARI, 1992, p. 208).

\section{OUTRAS PALAVRAS}

Nada dessa cica de palavra triste em mim na boca

Travo trava mãe e papai, alma buena dicha loca

Neca desse sono de nunca jamais nem never more Sim, dizer que sim pra Cilu, pra Dedé pra Dadi e Dó

Crista do desejo o destino deslinda-se em beleza:

Outras palavras

Tudo seu azul tudo céu tudo azul e furtacor

Tudo meu amor tudo mel tudo amor e ouro e sol

Na televisão na palavra no átimo no chão Quero essa mulher solamente pra mim mas muito mais

Rima pra que faz tanto mas tudo dor amor e gozo:

Outras palavras

Nem vem que não tem vem que tem coração tamanho trem

Como na palavra palavra a palavra estou em mim

E fora de mim quando você parece que não dá

Você diz que diz em silêncio o que eu não desejo ouvir 
Tem me feito muito infeliz mas agora minha filha:

Outras palavras

Quase João Gil Ben muito bem mas barroco como eu

Cérebro máquina palavras sentidos corações

Hiperestesia Buarque voilá tu sais de cor

Tinjo-me romântico mas sou vadio computador

Só que sofri tanto que grita porém daqui pra a frente:

Outras palavras

Parafins gatins alphaluz sexonhei la guerrapaz

Ouraxé palávoras driz okê cris espacial

Projeitinho imanso ciumortevida vivavid

Lambetelho frúturo orgasmaravalha-me Logun

Homenina nel paraís de felicidadania:

Outras palavras

Outras Palavras, Caetano Veloso (1981)

Neste texto as vidas marginais balbuciam um "discurso filosófico impuro, ameaçado, bastardo, híbrido" (DERRIDA, 1996, p.70) e "tomam para si todos os perigos que esta [filosofia] deve enfrentar, todas as condenações, perseguições e denegações que ela sofre" (DELEUZE; GUATTARI, 1992, p. 57). Poderíamos chamar essa filosofia de informe. A partir da interpretação filológica da palavra informação e suas estórias menores, o informe se apresenta como um elemento de articulação para se pensar a questão da balbúrdia e da linguagem. A balbúrdia entra em pauta devido ao uso pejorativo do Ministro da Educação brasileiro, alçando esta palavra e seus significados negativos à critério normativo, para desqualificar a atividade universitária.

Como comumente utilizado pelo discurso civilizatório, a balbúrdia é o signo festivo dos bárbaros. Todavia, buscamos abordar esta palavra por meio da perspectiva do informe. Retirando o que há de naturalizado na interpretação canônica, colocando em jogo elementos práticos e exemplificando a partir de atores do mundo cultural, buscamos enxergar panoramicamente como a linguagem e a balbúrdia se relacionam através da máquina antropológica ocidental e seus dispositivos de exceção. Esta linha de abordagem assinala para o discurso antropocêntrico, etnocêntrico e logocêntrico que o atual discurso oficial promove contra a Universidade Pública e seus atores. Entretanto, com o propósito de modificar as condições de interpretação da balbúrdia, desenvolvemos uma indicação furtiva de uma máquina contrária, onde a balbúrdia anuncia o tropel dos seres informes, povos menores tomados por um devir-revolucionário, sempre em devir, sempre inacabado. Este povo informe mira a subversão e a transformação estrutural das camadas interpretativas dos saberes, gaguejando a 
linguagem, hesitando-a num delírio para além dos próprios sulcos. À espera dos bárbaros, outras palavras escrevemos por esse povo por vir.

À espera dos bárbaros

- Que esperamos, reunidos na ágora?

É que hoje os bárbaros chegam.

- Por que tanta abulia no Senado?

Por que assentam os Senadores? Por que não ditam normas?

Porque os bárbaros chegam hoje.

Que normas vão editar os Senadores?

Quando chegarem, os bárbaros ditarão as normas.

- Por que o Autocrátor levantou-se tão cedo

E está sentado frente à Porta Nobre da cidade

Posto em seu trono, portando insígnias e coroa?

Porque os bárbaros chegam hoje.

E o Autocrátor espera receber

O seu chefe. Mais do que isto, predispôs

Para ele o dom de um pergaminho. Ali

Fez inscrever profusos títulos e nomes sonoros.

- Por que nossos dois cônsules e os pretores saíram

Esta manhã com togas rubras, com finos bordados de agulha?

Por que essas braçadeiras que portam, pesadas de ametistas,

E os anéis dactílicos lampejando reflexos de esmeralda?

Por que ostentam hoje os cetros preciosos,

Esplêndido lavor de cinzel, amálgama de ouro e prata?

Porque os bárbaros chegam hoje

E toda essa parafernália deslumbra os bárbaros.

- Por que nossos bravos tribunos não acodem

Como sempre, a blasonar seu verbo, a perorar seus temas?

Porque os bárbaros chegam hoje,

E eles desprezam a oratória e a logorreia.

Por que de repente essa angústia,

Esse atropelo? (Todos os rostos de súbito sérios!)

Por que rápidas se esvaziam ruas e praças

$\mathrm{E}$ os antes reunidos retornam atônitos às casas?

Porque a noite chegou e os bárbaros não vieram.

E pessoas recém-vindas da zona fronteiriça

Murmuram que não mais bárbaros.

E nós, como vamos passar sem os bárbaros? 
Essa gente não rimava conosco, mas já era uma solução.

Konstantinos Kaváfis (1984) 


\section{REFERENCIAS}

AGAMBEN, Giorgio. O aberto: o homem e o animal. Lisboa: Ed. 70, 2011.

AGAMBEN, Giorgio. Altíssima pobreza: regras monásticas e formas de vida. São Paulo: Boitempo, 2014.

AGAMBEN, Giorgio. Infância e história: destruição da experiência e origem da história. Belo Horizonte: Editora UFMG, 2005.

AGAMBEN, Giorgio. O que é o contemporâneo? e outros ensaios. Chapecó: Argos, 2009.

AGOSTINI, Renata. MEC cortará verba de universidade por "balbúrdia" e já enquadra Unb, UFF e Ufba. O Estado de S. Paulo, São Paulo, 30 de abril de 2019.

ALMEIDA, Mauro W. B. A fórmula canônica do mito. In: QUEIROZ, Ruben C.; NOBRE, Renarde F. (eds.). Lévi-Strauss. Leituras Brasileiras. Belo Horizonte: Editora da Universidade Federal de Minas Gerais, 2008. p. 147-182.

ANDIFES. V Pesquisa do Perfil Socioeconômico dos Estudantes de Graduação das Universidades Federais. Brasília: FONAPRACE, 2018.

ARISTÓTELES. Metafísica. São Paulo: Loyola, 2002.

ARISTÓTELES. Poética. Lisboa: Fundação Calouste Gulbenkian, 2008.

ARISTÓTELES. Política. Lisboa: Vega, 1998.

BARROS, Manoel. Poesia completa. São Paulo: Leya, 2010.

BENJAMIN, Walter. Magia e técnica, arte e política: ensaios sobre a literatura e história da cultura. São Paulo: Brasiliense, 1987.

BITTENCOURT, P. V.; LOPES, P. C. João Guimarães Rosa. São Paulo: Expressão Popular, 2008.

BOURDIEU, Pierre. Espíritos de Estado: gênese e estrutura do campo burocrático. In: BOURDIEU, Pierre. Razões práticas: sobre a teoria da ação. Campinas: Papirus, 1996.

CASSIN, Barbara (Coord.). Dicionário dos intraduziveis: um vocabulário das filosofias. Belo Horizonte: Autêntica, 2018. v.1

CASSIN, Barbara. Jacques, o Sofista: Lacan, logos e psicanálise. Belo Horizonte: Autêntica, 2017.

CASTRO, Eduardo Viveiros de. A inconstância da alma selvagem. São Paulo: CosacNaify, 2002.

CASTRO, R. Ela é carioca: uma enciclopédia de Ipanema. São Paulo: Companhia das Letras, 1999. 
CESARINO, Pedro de Niemeyer. Donos e Duplos: relações de conhecimento, propriedade e autoria entre Marubo. Revista de Antropologia, v. 53, n. 1, 2010.

COLLODI, Carlo. As aventuras de Pinóquio: história de um boneco. São Paulo: Cosac Naify, 2014.

DELEUZE, Gilles. Crítica e clínica. São Paulo: Ed. 34, 1997.

DELEUZE, Gilles; GUATTARI, Félix. Kafka: por uma literatura menor. Rio de Janeiro: Imago, 1977.

DELEUZE, Gilles; GUATTARI, Félix. O que é a filosofia? São Paulo: Ed. 34, 1992.

DELEUZE, Gilles; GUATTARI, Félix. Mil Platôs: capitalismo e esquizofrenia. São Paulo: Ed. 34, 1995. v. 1.

DERRIDA, Jacques. Gramatologia. São Paulo: Perspectiva, 2013.

DERRIDA, Jacques. Khôra. Campinas: Papirus, 1996.

DUFFY, Michael. Hun. 2009. Disponível em: <https://www.firstworldwar.com/atoz/hun.htm>. Acesso em: 30 de agosto de 2019.

FOUCAULT, Michel. Vigiar e punir. Petrópolis: Vozes, 2011.

FRAZER, Sir James G. The golden bough: a study in magic and religion. New York: Macmillan, 1931.

KAVÁFIS, Konstantinos. À espera dos bárbaros. In: CAMPOS, HAROLDO. Kaváfis: Melopéia e Logopéia. Remate de Males, v. 4, p. 119-124, 1984.

LAPOUJADE, David. As existências mínimas. São Paulo: N-1 edições, 2017.

LÉVI-STRAUSS, Claude. A oleira ciumenta. São Paulo: Brasiliense, 1986.

MACIEL, L. C. Geração em transe: memórias do tempo do tropicalismo. Rio de Janeiro: Nova Fronteira, 1996.

MARICONDA, Pablo \& LACEY, Hugh. A águia e os estorninhos. Galileu e a autonomia da ciência. Tempo Social, v. 13, n. 1, p. 49-65, 2001.

MBEMBE, Achille. Crítica da razão negra. Lisboa: Antígona, 2014.

MENEZES, Vinícios Souza de. O sertão da palavra informação: o informe em língua de brincar. ENCONTRO NACIONAL DE PESQUISA EM CIÊNCIA DA INFORMAÇÃO, 19, 2018, Londrina. Anais... Londrina: Escola de Ciência da Informação da UEL, 2018. p. 272-292.

NIETZSCHE, Friedrich. Escritos sobre retórica. Madrid: Trotta, 2000. 
NIETZSCHE, Friedrich. Segunda consideração intempestiva: da utilidade e desvantagem da história para a vida. Rio de Janeiro: Relume Dumará, 2003.

NUNES, Givanildo Brito. Entre o riso e o insulto: O Pasquim, Caetano, Gil, Simonal e as lutas simbólicas nos anos de chumbo. (Dissertação de Mestrado). 2016. 186 f. Dissertação (Mestrado em Memória: Linguagem e Sociedade), Universidade Estadual do Sudoeste da Bahia, 2016

PLATÃO. Filebo, Timeo, Critias. Madrid: Grecos, 1992.

ROSA, João Guimarães. Grande Sertão: veredas. Rio de Janeiro: Nova Fronteira, 2006.

SALDAÑA, Paulo. Corte de R\$ 926 milhões na Educação foi para pagar emendas, diz Weintraub. Folha de São Paulo, 16 de agosto de 2019.

SELIGMANN-SILVA, M. Walter Benjamin e os sistemas de escritura. In: O local da diferença: ensaios sobre memória, arte, literatura e tradução. São Paulo: Editora 34, 2005. p. 181-211.

SIMAS, Luiz Antonio; RUFINO, Luiz. Fogo no mato: a ciência encantada das macumbas. Rio de Janeiro: Mórula, 2018.

SPIVAK, Gayatri Chakravorty. Pode o subalterno falar? Belo Horizonte: Ed. UFMG, 2010.

VELOSO, Caetano; BETHANIA, Maria; GIL, Gilberto; COSTA, Gal. Doces Bárbaros. São Paulo: Philips, 1976. 2 discos sonoros (84 min).

VELOSO, Caetano. Outras palavras. Rio de Janeiro: Universal Music, 1981. 1 disco sonoro (40 $\min )$.

VITOR, Frederico. Bolsonaro vê imigrantes como "ameaça" e chama refugiados de "a escória do mundo". Jornal Opção, edição 2097, 18 de setembro de 2015.

ZIRALDO. Ziraldo e a invasão. O Pasquim, Rio de Janeiro, n. 141, p. 10-11, 1972. 